\title{
GENETIC DIVERSITY AMONG Colletotrichum Sublineolum PATHOTYPES ISOLATED FROM SORGHUM (Sorghum bicolor)
}

\author{
JOSÉ EDSON FONTES FIGUEIREDO ${ }^{1,4}$, HENRIQUE CESTARI DEPAOLI ${ }^{2}$, VINÍCIO TADEU DA \\ SILVA COELHO ${ }^{3}$, CARLOS ROBERTO CASELA ${ }^{1}$, ALEXANDRE DA SILVA FERREIRA ${ }^{1}$, CLÁUDIA \\ TEIXEIRA GUIMARÃES ${ }^{1}$, ELIANE APARECIDA GOMES ${ }^{1}$ and WELLINGTON BRESSAN ${ }^{1}$
}

\begin{abstract}
${ }^{1}$ Embrapa Milho e Sorgo, Caixa Postal 151, CEP 35701-970, Sete Lagoas, MG, Brazil
${ }^{2}$ Universidade de São Paulo, Faculdade de Medicina de Ribeirão Preto, Departamento de Genética, USP-FMRP, CEP 14049-900 Ribeirão Preto, SP, Brazil

${ }^{3}$ Universidade Federal de Minas Gerais, Instituto de Ciências Biológicas, Departamento de Bioquímica e Imunologia, CEP 31270-901, Belo Horizonte, MG, Brazil

${ }^{4}$ Corresponding author - e-mail: jeff@ cnpms.embrapa.br
\end{abstract}

Revista Brasileira de Milho e Sorgo, v.5, n.2, p.304-318, 2006

\begin{abstract}
Sorghum anthracnose, caused by Colletotrichum sublineolum is a serious disease in Brazil. The fungus is highly variable pathogenically with many physiological races. The present study was made to evaluate the usefulness of molecular methods (SDS-PAGE, RAPD, ARDRA and rDNA sequencing) for identifying C. sublineolum pathotypes isolated from sorghum. Although protein profile (SDS-PAGE) showed a relative low level of polymorphism, differences could be observed due to presence/absence of some polypeptides as well as to intensity of some bands among pathotypes. DNA profile of arbitrarily amplified sequences (RAPD) using sixteen random primers revealed a high degree of polymorphism while amplified rDNA (ITS region and 18S gene) digested with six different restriction enzymes (ARDRA) showed similar patterns. Nucleotide sequencing analysis of the complete ITS region and partial sequencing of 18S rRNA gene were useful for revealing genetic differences among the five pathotypes. In the present study, RAPD and rDNA sequencing were the most profitable methods for identifying $C$. sublineolum pathotypes.
\end{abstract}

Key words: Colletotrichum sublineolum, Sorghum bicolor, SDS-PAGE, RAPD, ARDRA, rDNA sequencing

\section{DIVERSIDADE GENÉTICA ENTRE PATÓTIPOS DE Colletotrichum Sublineolum ISOLADOS DO SORGO (Sorghum bicolor)}

\begin{abstract}
RESUMO - A antracnose do sorgo, causada por Colletotrichum sublineolum, é séria doença, no Brasil. O fungo é altamente variável do ponto de vista patogênico e várias raças têm sido noticiadas. Este estudo foi realizado com o objetivo de avaliar a utilidade de métodos moleculares (SDS-PAGE, RAPD, ARDRA e seqüenciamento de rDNA) para identificar patótipos de $C$. sublineolum isolados do sorgo. Embora o perfil protéico (SDS-PAGE) tenha mostrado baixo grau de polimorfismo, foi possível observar diferenças devido à presença/ausência de alguns polipeptídios, bem como diferenças quanto à intensidade de algumas bandas. O perfil de DNA amplificado arbitrariamente (RAPD), usando dezeseis primers aleatórios, revelou elevado grau de polimorfismo entre os
\end{abstract}


patótipos, enquanto que o produto da amplificação de rDNA (região ITS e gene 18S), digerido com seis enzimas de restrição diferentes (ARDRA), apresentou padrão similar. Análise de nucleotídeos da sequiência completa da região ITS e do seqüenciamento parcial do gene 18S rRNA revelaram diferenças genéticas entre os cinco patótipos. Entre os métodos testados no presente estudo, RAPD e sequienciamento de rDNA foram mais efetivos para identificar patótipos de $C$. sublineolum.

Palavras-chave: Colletotrichum sublineolum, Sorghum bicolor, SDS-PAGE, RAPD, ARDRA, seqüenciamento de rDNA

Sorghum bicolor [(L.) Moench] has been one of the most important crops in arid and semiarid regions of the world for more than three thousand years (Doggett, 1976). Nowadays, this crop is essential for human life on marginal lands along the poorest regions of the world (Frederiksen, 1986; ICRISAT, 1976). In the last few decades the importance of sorghum has increased as a feed crop that can be grown as part of sustainable agroecosystem (ICRISAT, 1976). However, diseases are serious problem limiting sorghum expansion to the new agricultural frontiers particularly in hot semi-arid tropical environments (ICRISAT, 1976). Sorghum anthracnose caused by the fungus Colletotrichum sublineolum (Henn.) is a serious epidemic disease in many countries. C. sublineolum pathotypes are highly variable and may change even while attempts are being made for classifying its virulence or efforts are being made for controlling the pathogen in the field (Casela et al., 1995; 2001). Whether pathogen changes are due to genetic, physiological or environmental events, they must be investigated. The development of efficient tools for promptly identifying new pathogen genotypes would help researchers follow the shift in genetic make-up of the pathogen population, thus providing a dynamic picture of the interactions between the host and pathogen genotypes.
Brazil is a tropical country with a Continental dimension and highly heterogeneous environment. Many physiological races of $\mathrm{C}$. sublineolum infecting sorghum have been identified in Brazilian fields and new races appear every year (Casela \& Frederiksen, 1994; Casela et al., 2001). In addition, phenotypic and physiological differentiation among $C$. sublineolum pathotypes are not always straightforward methods (Casela, 1992; Frederiksen et al., 1995; Pande et al., 1991). These effectively turn the breeding for new resistant varieties a fastidious compromise (Mek \& Warren 1992; Guthrie et al., 1992). The knowledge concerning genetic diversity of $C$. sublineolum populations is crucial for disease management and for establishing the relationship among environmental variations and changes in pathotype aggressiveness (Casela, 1992; Casela et al., 2001; Wise et al., 1995). Even so, attempts are being made to define alternative protocols based on molecular techniques for quick and efficient identification of $C$. sublineolum pathotypes to be used as tool for helping phytopathologists achieve this objective.

Molecular methods based on protein profile (SDS-PAGE) and DNA analysis (RAPD and rDNA sequencing), have been widely used to address taxonomic tasks and genetic variation in plant pathogens (Amann et al., 1996; Clarkson, 
1992; Di Cello et al., 1997; Gürtler \& Stanisich, 1996; Khachatourians, 1996; Lane, 1991; Lane et al., 1985; Weisburg et al., 1991). Protein markers (SDS-PAGE) are based in pattern of gene expression and, in many cases are able to reveal differences in gene products and gene expression among individuals. The random amplified polymorphic DNA (RAPD) is a powerful technique for fingerprinting individual organism and for estimating similarity within and between populations and species. (Bruijn et al., 1996; Guthrie et al., 1992; Honeycutt et al., 1995; Vilgalys et al., 1994). RAPD has been successfully used for addressing genetic variation in plant pathogens (Carbone \& Kohn, 1993; Chen, 1992; Vaillancourt \& Hanau, 1992; Welsh \& McClelland, 1990; Williams et al., 1990).

In the last two decades, ribosomal RNA genes have been chosen for taxonomic and phylogenetic studies in many groups of organisms. In a single cell, rRNA genes are present in multiple copies containing variable and conserved regions. Since ribosomes are ubiquitous in living organisms, rDNA analysis allows comparisons between widely different taxonomic groups and provides valuable information for phylogenetic studies examining relationships between higher taxa (Gerbi, 1986; Herion et al., 1992; Hibbett \& Dixon, 1991; Hibbett, 1992; Lee \& Taylor, 1992; O’Donnell, 1992). However, DNA sequencing is a laborious and expensive proposition if a great number of different related organisms have to be studied. Alternatively, restriction analysis of the intergenic spacer region of rDNA repeats (ARDRA) is a quick and inexpensive method and has been useful for examining genetic variability of multiple pathotypes of the same species or related species. ARDRA was successfully applied for strain identification in Fusarium oxysporum
(Alves-Santos et al., 1999; Appel \& Gordon, 1995; 1996; Chakrabarti et al., 2001; Latha et al., 2003), Pyrenophora graminea (Pecchia et al., 1998; 2004) and other eukariotic species (Clark et al., 1995; Medlin et al., 1988).

In the present study, molecular techniques based on protein (SDS-PAGE) and DNA markers (RAPD, ARDRA, rDNA sequencing) were applied for evaluating their usefulness for identifying $C$. sublineolum pathotypes isolated from sorghum cultivated in Brazilian fields. To achieve this, single spores of five $C$. sublineolum previously characterized as pathotypes $30 \mathrm{C}, 15 \mathrm{E}$, 15C, 31B, and 29A (Casela \& Ferreira, unpublished results) were used. Pathotypes were collected from Capinópolis (30C), Cravinhos (15E and 15C) and Sete Lagoas (31B and 29A) in fields of cultivated sorghum showing symptoms of anthracnose. After single spore isolation, each pathotype was cultured in a flask containing $250 \mathrm{~mL}$ of BCYE (4\% L-Cysteine, $11.5 \mathrm{~g}$ Yeast Extract, $1.5 \mathrm{~g}$ charcoal activated, $6 \mathrm{~g}$ ACES buffer, $1 \mathrm{~g}$ a-ketoglutarate, $2.5 \%$ ferric pyrophosphate, $17 \mathrm{~g}$ agar. $\mathrm{L}^{-1}, \mathrm{pH}$ 6.8) medium for $72 \mathrm{~h}$ at $25{ }^{\circ} \mathrm{C}$. Mycelial mass was harvested, washed three times with distilled water and briefly dried in a sterile filter paper. For long-term storage, fungus mycelia were harvested from Petri dishes and maintained in sterilized mineral oil at $-80{ }^{\circ} \mathrm{C}$.

SDS-PAGE was performed according to Laemmli (1970) and Jackman (1985). Freshly cultured mycelium was washed three times with $10 \mathrm{~mL}$ of TE buffer (10 mM Tris/HCl pH 8.0, 1 mM EDTA) and stored for several months at -80 ${ }^{\circ} \mathrm{C}$ until used. Mycelial mass (200 mg) of each isolate were powdered with liquid nitrogen, using a pestle and a mortar, and transferred to a $1.5 \mathrm{~mL}$ microcentrifuge tubes containing $100 \mathrm{~mL}$ of sample buffer (62.5 mM Tris- $\mathrm{HCl}$ pH 8.0, $20 \%$ 
(v/v) glycerol, 2\% SDS, 5\% b-mercaptoethanol, $0.02 \%$ bromophenol blue). Samples were heated for 10 minutes in boiled water and immediately placed on ice for five minutes. In the next step, samples were centrifuged for $10 \mathrm{~min}$ at $3000 \mathrm{rpm}$ and $15 \mathrm{~mL}$ of supernatant were loaded onto a $12 \%$ acrylamide gel. Electrophoresis was performed in $10 \%$ Tris-Glicine buffer $(0.025 \mathrm{M}$ Tris base, $0.192 \mathrm{M}$ glicine, $0.1 \%$ SDS pH 6,8) with Protean II minigel electrophoretic system (Bio-Rad Laboratories, Mississagua, ON) at $60 \mathrm{~V}$ for $1 \mathrm{~h}$. After electrophoresis, protein were visualized by coomassie blue staining method (Laemmli, 1970) and photographed with Eagle Eye System (Stratagene, La Jolla, CA).

Genomic DNA extraction was performed by a modified extraction protocol (Guthrie et al., 1992). Briefly, $500 \mathrm{mg}$ of dried mycelial mass of each isolate were powered in liquid nitrogen using a mortar and pestle, and transferred to $50 \mathrm{~mL}$ propilene tubes containing $5 \mathrm{~mL}$ of extraction buffer $(0.1 \mathrm{M}$ Tris- $\mathrm{HCl} \mathrm{pH} 8.0 ; 0.2 \mathrm{M} \mathrm{NaCl} ; 0.02$ M EDTA; 1,0\% SDS; $0.1 \%$ b-mercaptoethanol). Each tube was vigorously agitated for obtaining a uniform suspension without lumps and then incubated for $15 \mathrm{~min}$ at room temperature. Afterwards, an equal volume of chloroform:isoamyl alcohol $(24: 1 \mathrm{v} / \mathrm{v})$ was added to each sample, vigorously agitated, and incubated $10 \mathrm{~min}$ at room temperature. Cell debris was removed by centrifugation at $4{ }^{\circ} \mathrm{C}$ with $8000 \mathrm{rpm}$ for 10 minutes. Aliquots of $5 \mathrm{~mL}$ of the supernatant layer were transferred to a $50 \mathrm{~mL}$ propilene tube and an equal volume of ice cold ethanol was added to each sample and gently inverted several times to precipitate nucleic acids. Nucleic acids were spooled out on a glass hook, briefly washed in $70 \%$ ethanol and dissolved with $0,5 \mathrm{~mL}$ of TE buffer containing $40 \mathrm{mg} / \mathrm{mL}$ RNAse $\mathrm{H}$. The quality of DNA was checked by spectrophotometer measures (OD 260/280) and by electrophoresis in $1 \%$ agarose gel stained with ethidium bromide. The final concentration of DNA was adjusted to $25 \mathrm{ng} / \mathrm{mL}$.

RAPD reaction was performed in a final volume of $25 \mathrm{~mL}$ containing $10 \mathrm{mM}$ Tris- $\mathrm{HCl}$, $\mathrm{pH} 8.3,50 \mathrm{mM} \mathrm{KCl}, 2.0 \mathrm{mM} \mathrm{MgCl} 2,0.1 \mathrm{mM}$ of each deoxynucleotide triphosphate, $0.4 \mathrm{mM}$ primer, $1 \mathrm{U}$ of Taq DNA polymerase (Phoneutria, Belo Horizonte, Brazil) and $25 \mathrm{ng}$ of DNA template. The following sixteen 10-mer primers (Operon Technologies, Alameda, CA) were used: OPA 5; OPA 6; OPA 8; OPA 12; OPA 14; OPA 15; OPA 17; OPA 18; OPA 19; OPA 20; OPT 1; OPT 2; OPT 3; OPT 4; OPT 5; OPT 6. DNA amplifications were made in thermocycler (PTC100, MJ Research MS, USA) programmed for an initial melt of $1 \mathrm{~min}$ for denaturation at $94^{\circ} \mathrm{C}$, followed by 30 cycles of $94^{\circ} \mathrm{C}$ for $15 \mathrm{~s} ; 35^{\circ} \mathrm{C}$ for $30 \mathrm{~s}$ (annealing); $72^{\circ} \mathrm{C}$ for $30 \mathrm{~s}$ (extension). An additional step at $72^{\circ} \mathrm{C}$ for $10 \mathrm{~min}$ was performed in the final of 30 cycles and fast ramp was applied in all steps. Control tubes containing master mix without template DNA were included in each run and reactions were repeated at least three times to check the reproducibility of amplified DNA (Dassanayake \& Samaranayake, 2000). The PCR products were electrophoresed in agarose gel (1.2\%) immersed in 0.5 TBE buffer ( $89 \mathrm{mM}$ Trisborate, $2.5 \mathrm{mM}$ EDTA, $\mathrm{pH} 8.0$ ) containing $10 \mathrm{mg} /$ $\mathrm{mL}$ of ethidium bromide. The gel was run for $4 \mathrm{~h}$ with an initial step of $15 \mathrm{~min}$ at $100 \mathrm{~V}$ followed by $75 \mathrm{~V}$, and visualized with UV light and photographed with Eagle Eye System (Stratagene, La Jolla, CA).

Amplifications of ribosomal RNA genes (rDNA) were performed using universal primers for ITS region (Internal Transcribed Spacer) and for $18 \mathrm{~S}$ rRNA gene. All primers represent conserved regions of fungi species 
(Bruns et al, 1992; Gargas \& DePriest, 1996; White et al., 1990). The ITS DNA was amplified with primers ITS1 (forward) (5'T C C G TA G G T G A A C C T G C G G - 3') complementary to $18 \mathrm{~S}$ gene and ITS4 (reverse) (5'-TCCTCCGCTTATTGATATGC-3') that anneal with the 28S gene (Gargas \& DePriest, 1996; Hibbett, 1992). The 18S rRNA gene was amplified by using NS1F (5'GTAGTCATATGCTTGTCTC-3') and NS8R (5'-TCCGCAGGTTCACCTACGGA-3') primers (Gargas \& DePriest, 1996; Hibbett, 1992). PCR reactions were made with $10-20 \mathrm{ng}$ of C. sublineolum genomic DNA plus $2.5 \mathrm{~mL}$ 10X PCR buffer (200 mM Tris- $\mathrm{HCl}(\mathrm{pH} 8.4)$ and $500 \mathrm{mM} \mathrm{KCl}$ ), $2.0 \mathrm{mM}$ of each primer, $25 \mathrm{mM}$ dNTP, $2,5 \mathrm{mM} \mathrm{MgCl}$, and $1 \mathrm{U}$ of Taq DNA polymerase (Phoneutria, Belo Horizonte, Brazil) in a total volume of $25 \mathrm{~mL}$. Thermocycling was performed in a model PTC-100 thermalcycler machine (MJ Research, MS, USA) with the following conditions: one cycle for denaturation of DNA samples at $94{ }^{\circ} \mathrm{C}$ for $1 \mathrm{~min}, 30$ cycles of $1 \mathrm{~min}$ at $94{ }^{\circ} \mathrm{C}, 1 \mathrm{~min}$ at $50^{\circ} \mathrm{C}$ (annealing) and 2 $\min$ at $72^{\circ} \mathrm{C}$ (extension). Finally, reactions were incubated for $10 \mathrm{~min}$ at $72{ }^{\circ} \mathrm{C}$. Control tubes containing master mix without template DNA were included in each run and reproducibility was checked out by replicas for each reaction. Aliquots of $500 \mathrm{ng}$ of ITS and 18S rDNA amplified products were digested for $4 \mathrm{~h}$ with 5 $\mathrm{U}$ of tetrameric (Alu I, Mbo I, Msp I and Sau3A I) and hexameric (EcoRI) restriction endonucleases (Invitrogen ${ }^{\mathrm{TM}}$, Carlsbad, CA) containing the appropriated buffer. DNA digests were analyzed by horizontal gel electrophoresis at $6 \mathrm{~V} / \mathrm{cm}^{2}$ in $1.5 \%$ agarose gel (wt/v) for ITS or $1.0 \%$ agarose gel for $18 \mathrm{~S}$ in $1 \mathrm{X}$ TAE buffer (0.04M Tris-acetate, $0.001 \mathrm{M}$ EDTA, $\mathrm{pH} 8.0)$ containing ethidium bromide $(0.5 \mathrm{mg} / \mathrm{L})$. Gels were visualized under UV light, photographed and the fingerprints were compared visually with the overview gels. Alternatively, digested PCR products of ITS region were resolved in 10\% poliacrylamide gel and silver stained (data not shown).

Sequencing reactions of rDNA (ITS and $18 \mathrm{~S})$ were performed in a total volume of $25 \mathrm{ml}$ containing 200-300 ng of amplified rDNA, 20 pmol of primer (ITS1, ITS4, NS1F, or NS8R) and $8.0 \mathrm{~mL}$ reaction premix (Applied Biosystems, Lincoln Centre Drive Foster City, USA). Reaction conditions were established with an initial step of DNA denaturation at $96^{\circ} \mathrm{C}$ for $30 \mathrm{~s}$, followed by 25 cycles of $30 \mathrm{~s}$ at $96^{\circ} \mathrm{C}$, annealing for $15 \mathrm{~s}$ at $50{ }^{\circ} \mathrm{C}$ and extension for $4 \mathrm{~min}$ at $60{ }^{\circ} \mathrm{C}$. The reaction products were precipitated with $2,5 \mathrm{~mL}$ of $3 \mathrm{M}$ sodium acetate, $\mathrm{pH} 4.6$ plus $50 \mathrm{~mL} 95 \%$ cold ethanol for $10 \mathrm{~min}$ on ice, centrifuged for $30 \mathrm{~min}$ at $16000 \mathrm{rpm}$, and washed with $250 \mathrm{~mL}$ of $70 \%$ ethanol. Sequencing was performed in an automatic sequencer (ABI-377, Applied Biosystems, Lincoln Centre Drive Foster City, USA) and repeated at least three times. $C$. sublineolum rDNA sequences generated in the present study were deposited in Genbank database and their respectively accession numbers are shown in Table 1.

DNA patterns of RAPD were recorded in a binary form (presence or absence) for constructing a dendrogram. Amplified fragments lower than $200 \mathrm{bp}$ and faint bands were neglected. Dendrogram was constructed from the distance matrix by using the unweighted-pair group method with arithmetic mean (UPGMA). Both procedures were done with the Statistica software version 4.2 for windows (StatSoft, Inc. USA). DNA sequences of $18 \mathrm{~S}$ rRNA gene and internal transcribed spacer region of $18-28 \mathrm{~S}$ of $C$. sublineolum, as well as other fungi sequences 
TABLE 1. GenBank accession numbers generated by DNA sequencing of ITS region spacer, 5.8S rRNA and partial sequencing of 5'- and 3'- end of 18S rRNA gene of five C. sublineolum pathotypes isolated from Brazilian sorghum.

\begin{tabular}{|c|c|c|c|}
\hline $\begin{array}{c}\text { C. sublineolum } \\
\text { pathotypes }\end{array}$ & $\begin{array}{c}\text { Primers* and } \\
\text { annealing position }\end{array}$ & rDNA Sequences & $\begin{array}{r}\text { Accession } \\
\text { numbers }\end{array}$ \\
\hline $30 \mathrm{C}$ & $\begin{array}{c}\text { NS1F } \\
(18 \mathrm{~S} 5 \text { '- end })\end{array}$ & $5^{\prime}-$ partial $18 \mathrm{~S}$ & AY622774 \\
\hline $30 \mathrm{C}$ & $\begin{array}{c}\text { NS8R } \\
\text { (18S 3'- end) }\end{array}$ & $3^{\prime}-$ partial $18 S$ & AY622779 \\
\hline $30 \mathrm{C}$ & $\begin{array}{l}\text { ITS1 (18S 3'- end) } \\
\text { and } \\
\text { ITS4 (28S 5' end) }\end{array}$ & ITS region ** & AY622784 \\
\hline $15 \mathrm{E}$ & $\begin{array}{c}\text { NS1F } \\
(18 \mathrm{~S} 5 \text { '- end })\end{array}$ & $5^{\prime}-$ partial $18 S$ & AY622775 \\
\hline $15 \mathrm{E}$ & $\begin{array}{c}\text { NS8R } \\
(18 \mathrm{~S} \mathrm{3} \text { '- end) }\end{array}$ & $3^{\prime}$ - partial $18 \mathrm{~S}$ & AY622780 \\
\hline $15 \mathrm{E}$ & $\begin{array}{c}\text { ITS1 (18S 3'- end) } \\
\text { and } \\
\text { ITS4 (28S 5'- end) }\end{array}$ & ITS region ** & AY622785 \\
\hline $15 \mathrm{C}$ & $\begin{array}{c}\text { NS1F } \\
\left(185^{\prime} \text { end }\right)\end{array}$ & $5^{\prime}-$ partial $18 S$ & AY618464 \\
\hline $15 \mathrm{C}$ & $\begin{array}{c}\text { NSR8 } \\
\text { (18S 3'- end) }\end{array}$ & $3^{\prime}-$ partial $18 \mathrm{~S}$ & AY622778 \\
\hline $15 \mathrm{C}$ & $\begin{array}{c}\text { ITS1 (18S 3'- end) } \\
\text { and } \\
\text { ITS4 (28S 5'- end) }\end{array}$ & ITS region ** & AY622783 \\
\hline $31 \mathrm{~B}$ & $\begin{array}{c}\text { NS1F } \\
\left(18 \mathrm{~S} 5^{\prime}-\text { end }\right)\end{array}$ & $5^{\prime}-$ partial $18 \mathrm{~S}$ & AY618463 \\
\hline $31 \mathrm{~B}$ & $\begin{array}{c}\text { NS8R } \\
(18 \mathrm{~S} \mathrm{3} \text { '- end) }\end{array}$ & $3{ }^{\prime}-$ partial $18 \mathrm{~S}$ & AY622777 \\
\hline 31B & $\begin{array}{c}\text { ITS1 (18S 3'- end) } \\
\text { and } \\
\text { ITS4 (28S 5'- end) }\end{array}$ & ITS region ** & AY622782 \\
\hline $29 \mathrm{~A}$ & $\begin{array}{c}\text { NS1F } \\
\left(18 \mathrm{~S} 5^{\prime}-\text { end }\right)\end{array}$ & $5^{\prime}-$ partial $18 \mathrm{~S}$ & AY618462 \\
\hline $29 \mathrm{~A}$ & $\begin{array}{c}\text { NS8R } \\
\text { (18S 3' end) }\end{array}$ & $3^{\prime}-$ partial $18 \mathrm{~S}$ & AY622776 \\
\hline $29 \mathrm{~A}$ & $\begin{array}{c}\text { ITS1 (18S 3'- end) } \\
\text { and } \\
\text { ITS4 }(28 \mathrm{~S} 5 \text { '- end })\end{array}$ & ITS region ** & AY622781 \\
\hline
\end{tabular}


available in the GenBank database were used for comparison (data not shown). rDNA sequences were aligned using the CLUSTAL W Multiple Sequences Alignment program (Thompson et al., 1994) and dendrograms were constructed from the distance matrix by using the unweighted-pair group method with arithmetic mean (UPGMA). Both procedures were done with software Statistica, version 4.2 for windows (StatSoft, Inc. USA).
SDS-PAGE of total protein extract from mycelial mass of five $C$. sublineolum pathotypes showed a relative homogenous profile and most of the bands were shared by all pathotypes. The main differences among pathotypes were commonly related to intensity of certain bands (Figure 1). Although the existing differences allow discriminating each of the five $C$. sublineolum phenotype, it was stated that total

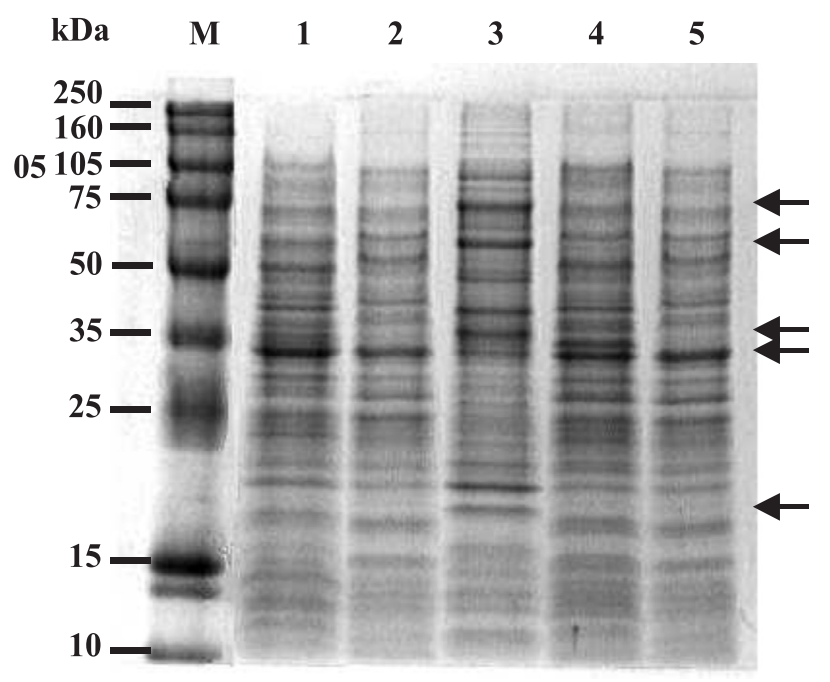

FIGURE 1. Electrophoretical profile (SDS-PAGE) of total protein extract from mycelial mass of five $C$. sublineolum pathotypes. Some differences observed between pathotypes were indicated by arrows. $\mathrm{M}=$ molecular marker (Rainbow Molecular Weight Markers, New England Biolabs) while numbers indicate the pathotypes $29 \mathrm{~A}, 31 \mathrm{~B}, 15 \mathrm{C}, 30 \mathrm{C}$ and $15 \mathrm{E}$, respectively.

protein profile may not be an effective method for fingerprinting when a high number of pathotypes must be identified. Nevertheless, different results were observed with random amplified polymorphic DNA (RAPD). After previous screening, sixteen random primers were selected to assess genetic diversity among the five pathotypes. A high level of DNA polymorphism was detected, yielding a typical genomic fingerprint for each isolate. Fragment sizes of amplified DNA ranged from 0.2 to $2.5 \mathrm{~kb}$ and some bands were unique while others were present in all pathotypes (Figure 2). The number of polymorphic bands scored per primer varied from 5 to 8 and a total of 88 bands were used for cluster analysis. UPGMA algorithm generated a dendrogram with the five $C$. sublineolum pathotypes been clustered in two groups. Although the pathotypes from Cravinhos (15E and $15 \mathrm{C}$ ) and Sete Lagoas (29A and 31B) were separated, the pathotype from Capinópolis (30C) was grouped with the Sete Lagoas pathotypes (Figure 3). In a recently study applying RAPD and RFLP-PCR markers for identifying 


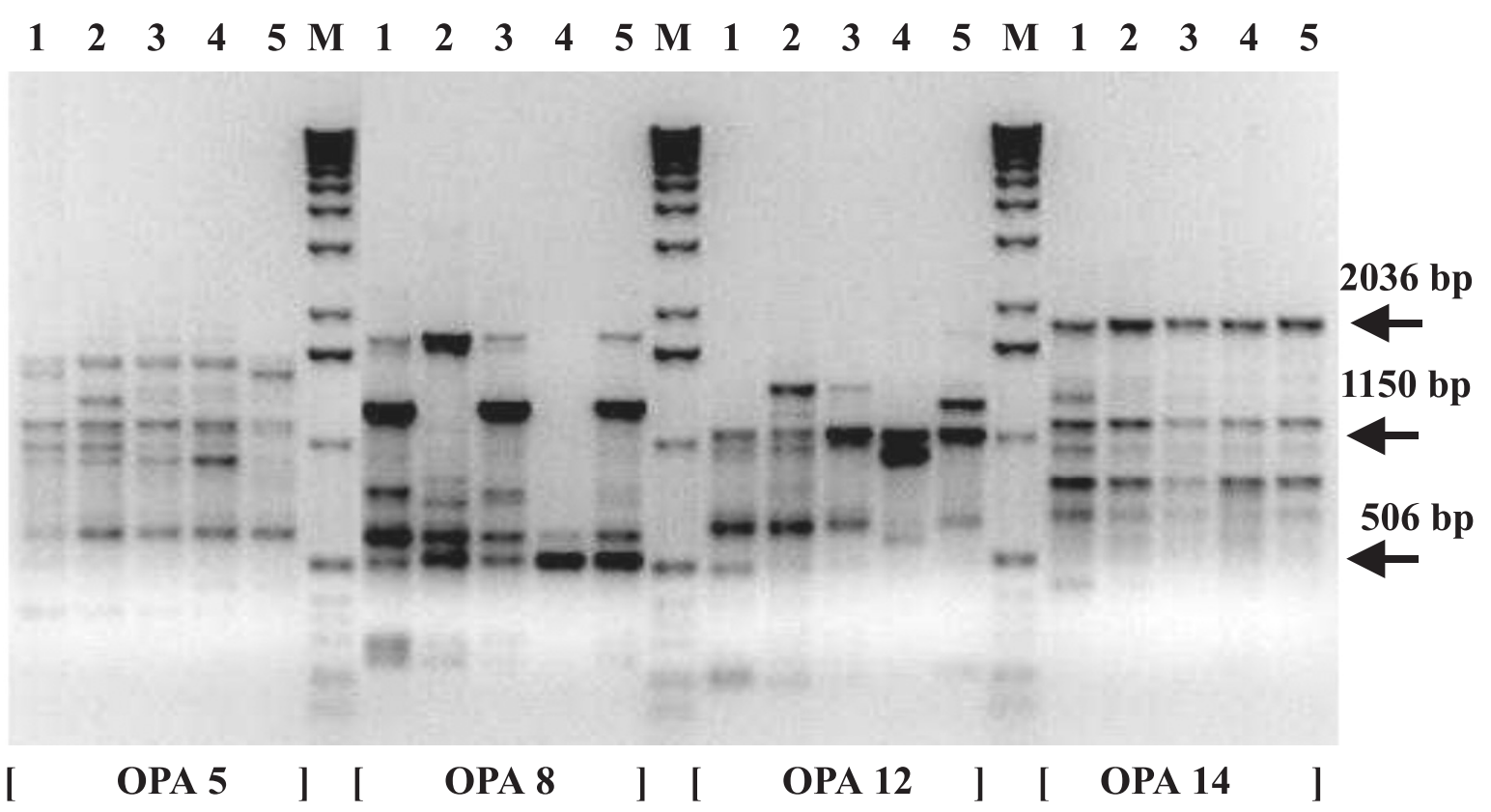

FIGURE 2. RAPD amplified products of five Colletotrichum sublineolum pathotypes resolved in an $1,2 \%$ agarose gel. $\mathrm{M}=1 \mathrm{~kb}$ molecular size marker Ladder (Invitrogen ${ }^{\mathrm{TM}}$, Carlsbad, CA). Lanes 1 through 5, RAPD patterns of fungus pathotypes 29A, 31B, 15C, 30C and 15E, respectively. Random primers $\left(\mathrm{OPERON}{ }^{\mathrm{TM}}\right)$ are indicated bellow the figure.

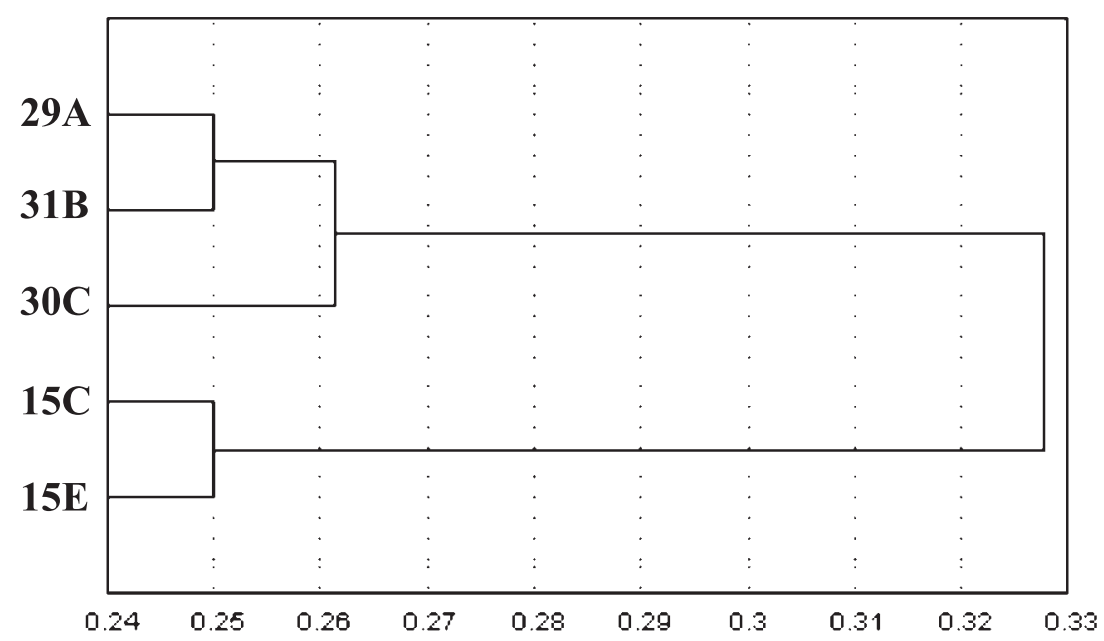

FIGURE 3. Dendrogram showing genetic relationships among five $C$. sublineolum pathotypes, based on RAPD patterns produced with sixteen random primers (OPERON, Technologies). The dendrogram was constructed from the distance matrix by using the unweighted-pair group method with arithmetic mean (UPGMA). Both procedures were done with the Statistica software for windows, version 4.2 (StatSoft, Inc. USA). Scale bar indicates dissimilarity between the five different pathotypes in percentage. 
Colletotrichum sublineolum isolated from four geographically distinct regions of Brazil revealed a high level of polymorphism for RAPD markers and all pathotypes were grouped according to place they were collected (Valério et al., 2005).
Amplified products of ITS region (560 bp) and $18 \mathrm{~S}$ rRNA gene $(2.0 \mathrm{~kb})$ of the five $C$. sublineolum pathotypes were digested with five different restriction enzymes (Figure 4). ARDRA profile was very poor and little information about

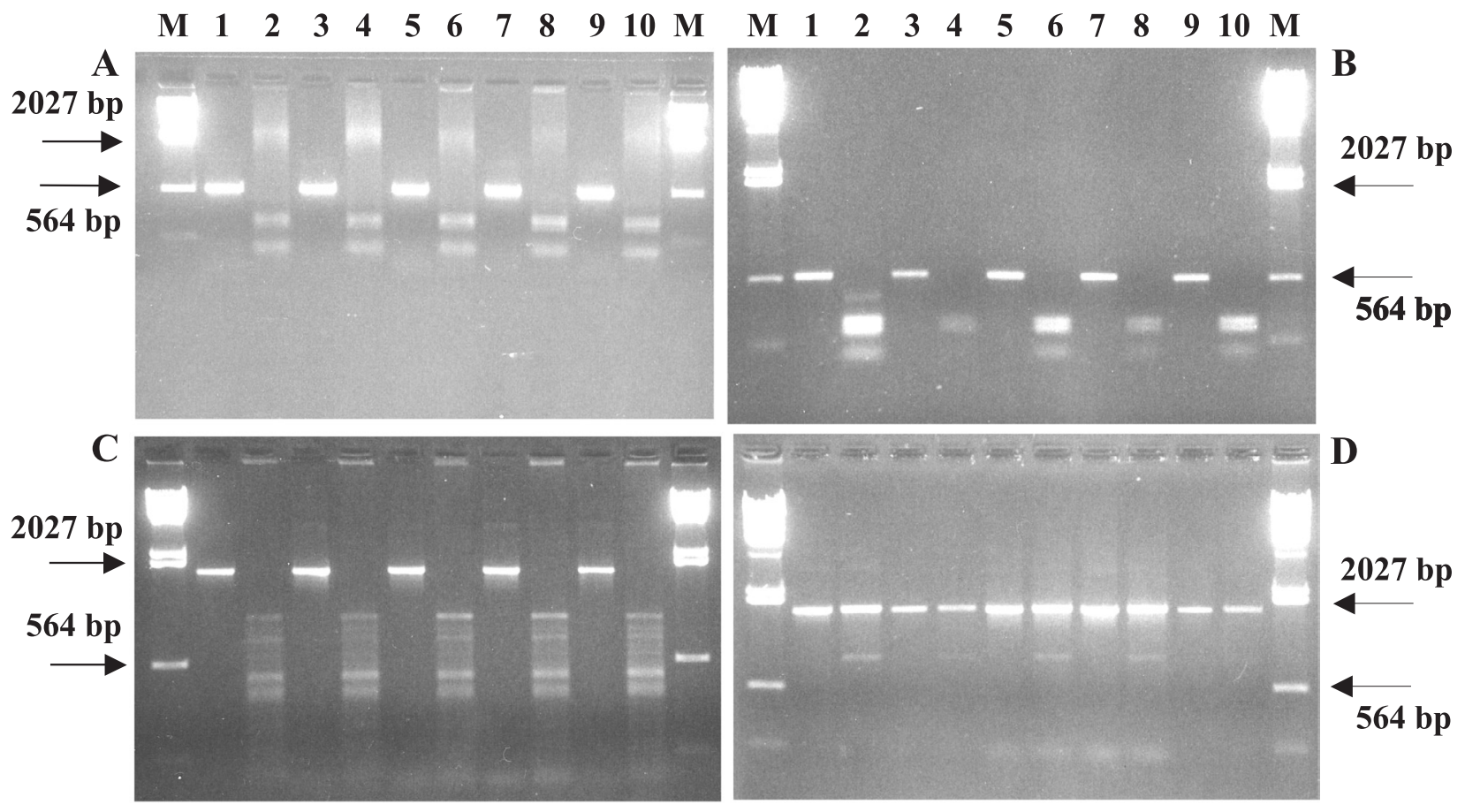

FIGURE 4. Agarose gel electrophoresis of PCR-amplified rDNA products from the internal spacer region (A and $\mathrm{B}$ ) and 18S rRNA gene (C and $\mathrm{D})$ of five Colletotrichum sublineolum pathotypes digested with endonucleases Sau3A I (A and C), Mbo I (B), and EcoR I (D). Lanes M, lambda Hind III molecular size marker ladder (Invitrogen ${ }^{\mathrm{TM}}$, Carlsbad, CA) . Lanes 1, 3, 5, 7 and 9 contain nondigested PCR products and lanes 2, 4, 6, 8 and 10 are ARDRA patterns of pathotypes 29A, 31B, $15 \mathrm{C}, 30 \mathrm{C}$ and $15 \mathrm{E}$, respectively.

pathotype identity could be obtained. Similar patterns of restricted DNA were observed for Alu I and Msp I (data not shown) and Sau3A I restriction enzymes (Figure 4). Mbo I and EcoR I restriction patterns were very similar and they were not effective to discriminate the five $C$. sublineolum pathotypes (Figure 4). In another study, RFLP over ITS domains and 5.8 rDNA genes of $C$. sublineolum did not show differences among the isolates (Valério et al., 2005). Although the high level of nucleotide conservation for restriction sites observed for ITS region, 5.8S rDNA and 18S rDNA genes of C. sublineolum in the present study, and for twelve restriction enzymes over ITS domain and 5.8S rDNA genes in another study (Valério et al., 2005), ARDRA profiles have been successfully used for species and strain 
differentiation in many fungi, prokaryotes and other eukaryotic species (Alves-Santos et al., 1999; Appel \& Gordon, 1995; 1996; Atkins et al., 2005; Chakrabarti et al., 2001; Clark \& Pung, 1994; Clark et al., 1995; Latha et al. 2003; Pecchia et al., 1998; 2004). Although ARDRA results in the present study and RFLP analysis of rDNA genes (Valério et al., 2005) were not suitable for genotiping C. sublineolum isolates, screening for RFLP variation using anonymous sized DNA fragments revealed a high level of variation at the DNA level in this specie (Rosewich et al., 1998).

PCR-amplified products comprising the ITS region of rDNA and both, 5'- and $3^{\prime}$ - ends of $18 \mathrm{~S}$ ribosomal gene of the five C. sublineolum pathotypes were sequenced and aligned using CLUSTAL W program (Thompson et al., 1994). Nucleotide sequences of ITS region generated by ITS1 (forward) and ITS4 (reverse) primers were overlapped and the entire ITS region with 5.8S ribosomal gene of the five $C$. sublineolum pathotypes comprising 560 base pairs in length could be determined. Nucleotide sequencing alignment of ITS region of the five $C$. sublineolum pathotypes revealed a high degree of similarity, and of the $560 \mathrm{bp}$ only 53 nucleotides were different (data not shown). In spite of the high level of nucleotide conservation for ITS region, the five $C$. sublineolum pathotypes could be clearly separated in five different races.

PCR-amplified 18S rRNA gene of the five C. sublineolum pathotypes were approximately $2,0 \mathrm{~kb}$ in length without detectable polymorphism. NS1F and NS8R primers were used for partial sequencing the $18 \mathrm{~S}$ rRNA gene and sequence alignments of 5'- and $3^{\prime}$ - end of $18 \mathrm{~S}$ gene were useful for identifying each $\mathrm{C}$. sublineolum pathotypes. Nucleotide comparison between the two 18S partial sequences of each isolate showed that 18NS8R sequence was more variable than $18 \mathrm{NS} 1 \mathrm{~F}$ sequence (data not shown). In addition, both $18 \mathrm{~S}$ partial sequences ( $5^{\prime}$ - and 3 '- end) were more polymorphic than sequences obtained for ITS region.

Nucleotide sequence divergence for ITS region and $18 \mathrm{~S}$ partial sequences (NS1F and NS8R) was estimated using the Jaccard method. A dendrogram was constructed from the distance matrix by using the UPGMA. Both procedures were done with the Statistica software, version 4.2 for windows (StatSoft, Inc. USA). Pathotypes from Sete Lagoas and Cravinhos were grouped in the same branch of dendrogram while the pathotype 30C, collected from Capinópolis, was separated from the others (Figure 5).

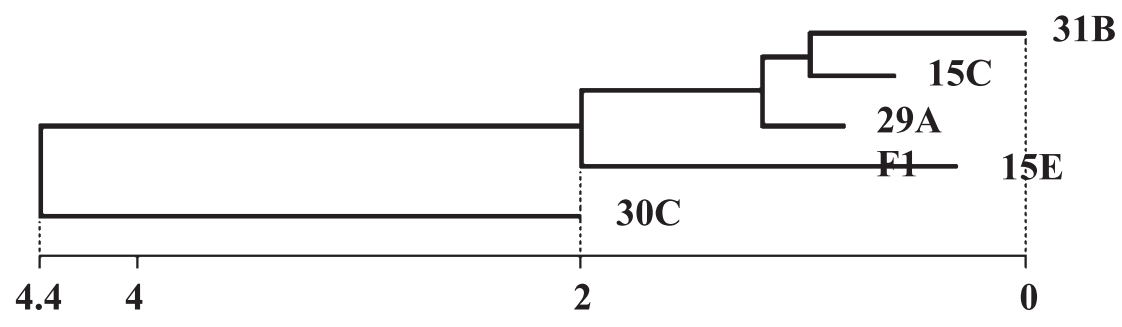

FIGURE 5. Dendrogram showing genetic relationships among C. sublineolum pathotypes, based on rDNA sequencing of ITS region and 18S gene. The dendrogram was constructed from the distance matrix by using the unweighted-pair group method with arithmetic mean (UPGMA). Both procedures were done with the Statistica software for windows, version 4.2 (StatSoft, Inc. USA). Scale bar indicates dissimilarity between the five different pathotypes in percentage. 
Dendrograms generated by RAPD (Figure 3) and rDNA sequencing approaches (Figure 5) are not comparable since clustering obtained by one method was disrupted when another method was used. Thus, results concerning genetic relationships among the five C. sublineolum pathotypes based in RAPD and rDNA sequencing analysis might be interpreted with caution. In the other hand, bootstrap analysis showed that $38 \%$ of RAPD scored DNA bands and $46 \%$ of nucleotide differences of rDNA were sufficient to produce nearly $98 \%$ of trustworthiness (data not shown).

In conclusion, among different molecular techniques (SDS-PAGE, RAPD, ARDRA and rDNA sequencing analysis) used in the present study for $C$ sublineolum identification, RAPD was the most reliable technique for revealing genetic diversity among $C$. sublineolum pathotypes while direct comparison of nucleotide sequences of amplified rDNA was the most informative technique and thus, the best method for determining taxonomic relationships among C. sublineolum pathotypes.

\section{ACKNOWLEDGEMENTS}

Authors wish to thank to Fundação de Amparo à Pesquisa do Estado de Minas Gerais FAPEMIG for financial support.

\section{Literature Cited}

ALVES-SANTOS, F. M.; BENITO, E. P.; ESLAVA, A. P.; DIAZ-MINGUEZ, J. M. Genetic diversity of Fusarium oxysporum strains from common bean fields in Spain. Applied and Environmental Microbiology, Washington, v. 65, n. 8, p. 3335-3340, 1999.

AMANN, R.; SNEIDR, J.; WAGNER, M.; LUDWIG, W.; SCHEIFLER, K. H. In situ visualization of high genetic diversity in a natural microbial community. Journal of Bacteriology, Washington, v. 178, n. 12, p. 34963500, 1996.

APPEL, D. J.; GORDON, T. R. Relationships among pathogenic and nonpathogenic isolates of Fusarium oxysporum based on the partial sequence of the intergenic spacer region of the ribosomal DNA. Molecular Plant Microbe Interactions, St. Paul, v. 9, n. 2, p. 125-138, 1996.

APPEL, D. J.; GORDON, T. R. Intraspecific variation within populations of Fusarium oxysporum based on RFLP analysis of the intergenic spacer region of the rDNA. Experimental Mycology, New York, v. 19, n. 2, p. 120-128, 1995.

ATKINS, S. D.; CLARK, I. M.; PANDE, S.; HIRSCH, P. R.; KERRY, B. R. The use of realtime PCR and species-specific primers for the identification and monitoring of Paecilomyces lilacinus. FEMS Microbiology ecology, Amsterdam, v. 51, n. 2, p. 257-264, 2005.

BRUIJN, F. J. de; RADEMAKER, J.; SCHNEIDERL, M.; ROSSBACHL, U.; LOUWS, F. J. Rep-PCR genomic fingerprinting of plant-associated bacteria and computerassisted phylogenetic analysis. In: Biology of Plant-microbe lnteraction; In: STACEY, B.; MULLIN, T.; GRESSHOFF, P. (Eds.). Biology of plant-microbe interaction. St. Paul: APS Press, 1996. p. 497-502.

BRUNS, T. D.; VILGALYS, R.; BARNS, S. M.; GONZALES, D.; HIBBETT, D. S.; LANE, D. J.; SIMON, L.; STICKEL, S.; SZARO, T. M.; WEISBURG, W. G.; SOGIN, M. L. Evolutionary relationships within the fungi: analysis of nuclear small subunit rRNA sequences. Molecular Phylogenetic and Evolution, Oxford, v. 1, p. 231-241, 1992. 
CARBONE, I.; KOHN, L. M. Ribosomal DNA sequence divergence within internal transcribed spacer I of the Sclerotiniaceae. Mycologia, New York, v. 85, p. 415-427, 1993.

CASELA, C. R. Investigations on the variability of the sorghum anthracnose fungus Colletotrichum graminicola. 1992. 166 f. Dissertation (Doctor of Phylosophy.) - Texas A\&M University, [College Station]

CASELA, C. R.; FREDERIKSEN, R. A. Variabilidade patogênica em isolamentos monospóricos de Colletotrichum graminicola, agente causal da antracnose do sorgo, originadas de uma única lesão e de culturas monospóricas. Fitopatologia Brasileira, Brasília, DF, v. 19, p. 149-153, 1994.

CASELA, C. R.; FERREIRA, A. S.; ZELLER, K. A.; LEVY, M. Pathotype variation in the sorghum anthracnose fungus: A phylogenetic perspective for resistance breeding. In: LESLIE, J. F.; FREDERIKSEN, R. A. (Eds.). Disease analysis through genetics and molecular biology: interdisciplinary bridges to improved sorghum and millet crops. Ames: Iowa State University Press, 1995. p.257-276.

CASELA, C. R.; FERREIRA, A. S.; SANTOS, F. G. Differences in competitive ability among races of Colletotrichum graminicola in mixtures. Fitopatologia Brasileira, Brasília, DF, v. 26, n. 2, p. 217-219, 2001.

CHAKRABARTI, A.; MARHAWA, R. K.; MONDAL, R.; TREHAN, A.; GUPTA, S.; RAO, R. D. S.; SETHI, S.; PADHYET, A. A. Generalized lymphadenopathy caused by Trichosporon asahii in a patient with Job's syndrome. Medical Mycology, Oxford, v. 40, n. 1, p. 83-86, 2002.
CHEN, W. Restriction fragment length polymorphism in enzymatically amplified ribosomal DNAs of three heterothalic Pythium species. Phytopathology, St. Paul, v. 82, p. 14671472, 1992.

CLARK, C. G.; PUNG, O. J. Host-specificity of ribosomal DNA variation in sylvatic Trypanosoma cruzi from North America. Molecular and Biochemical Parasitology, Amsterdam, v. 66, p.175-179, 1994.

CLARK, C. G.; MARTIN, D. S.; DIAMOND, L. S. Phylogenetic relationships among anuran trypanosomes as revealed by riboprinting. Journal of Eukaryotic Microbiology, Lawrence, v. 42, p. 92-96, 1995.

CLARKSON, J. M. Molecular approaches to the study of entomopathogenic fungi. In: LOMER, C. J.; PRIOR, C. (Eds.). Biological control of locusts and grasshoppers. Wallington: CAB, 1992. p. 191-199.

DASSANAYAKE, R. S.; SAMARANAYAKE, L. P. Characterization of the genetic diversity in superficial and systemic human pathotypes of Candida parapsilosis by randomly amplified polymorphic DNA (RAPD). APMIS: Acta Pathologica, Microbiologica et Immunologica Scandinavica, Kobenhavn, v. 108, n. 2, p. 153-158, 2000.

DI CELLO F.; BEVIVINO, A.; CHIARINI, L.; FANI, R.; PAFFETTI, D.; TABACCHIONI, S. DALMASTRI, C. Biodiversity of a Burkholderia cepacia population isolated from the maize rhizosphere at different plant growth stages. Applied and Environmental Microbiology, Washington, v. 63, n. 11, p. 4485-4493, 1997.

DOGGETT, H. Sorghum (Sorghum bicolor) (Gramineae, Andropogoneae). In: SIMMNODS, 
N. W. (Ed.). Evolution of crop plants. London: Longman, 1976. p. 112-117.

FREDERIKSEN, R. A.; THOMAS, M. D.; BANDYOPADHYAY, R.; MUGHOGHO, L. K. Variable pathogens of sorghum. In: LESLIE, J. F.; FREDERIKSEN, R. A. (Eds.). Disease analysis through genetics and molecular biology: interdisciplinary bridges to improved sorghum and millet crops. Ames: Iowa State University Press, 1995. p. 11-23.

FREDERIKSEN, R. A. Grain mold. In: FREDERIKSEN, R. A. (Ed.). Compendium of Sorghum Diseases. St. Paul: American Phytopathological Society, 1986. p. 36-38.

GARGAS, A.; DEPRIEST, P. T. A nomenclature for fungal PCR primers with examples from intron-containing SSU rDNA. Mycologia, New York, v. 88, p. 745-748, 1996.

GERBI, S. A. The evolution of eukaryotic ribosomal DNA. Biosystems, Amsterdam, v. 19, n. 4, p. 247-58, 1986.

GUTHRIE, P. A. I.; MAGILL, C. W.; FREDERIKSEN, R. A.; ODVODY, G. N. Random Amplified Polymorphic DNA markers a system for identifying and differentiating pathotypes of Colletotrichum graminicola. Phytopathology, St. Paul, v. 82, n. 8, p. 832-835, 1992.

GÜRTLER, V.; STANISICH, V. A. New approaches to typing and identification of bacteria using the 16S-23S rDNA spacer region. Microbiology, New York, v. 142, p. 3-16, 1996.

HERION, B.; LE TACON, F.; MARTIN, F. Rapid identification of genetic variation of ectomycorrizal fungi by amplification of ribosomal RNA genes. New Phytologist, Oxford, v. 122, p. 289-298, 1992.
HIBBETT, D. Ribosomal RNA and fungal systematics. Transactions of the Mycology Society of Japan, Tokyo, v. 33, p. 533-556, 1992.

HIBBETT, D. S.; DIXON, M. T. Ribosomal DNA: Molecular evolution and phylogenetic inference. Quarterly Review of Biology, Stony Brook, v. 66, p. 411-453, 1991.

HONEYCUTT, R. J.; SOBRAL, B. W. R.; McClelland, M. tRNA intergeneric spacers reveal polymorphisms diagnostic for Xanthomonas albilineans. Microbiology, New York, v. 141, p. 3229-3239, 1995.

ICRISAT ANNUAL REPORT 1975/1976. Hyderabad, 1976. 256 p.

JACKMAN, P. J. H. Bacterial taxonomy based on electrophoretic whole-cell protein patterns. In: GOODFELLOW, M.; MINNIKIN, D. E. (Eds.). Chemical methods in bacterial systematics. London: Academic Press, 1985. p. 115-129.

KHACHATOURIANS, G. G. Biochemistry and molecular biology of entomopathogenic fungi. In: HOWARD, D. H.; MILLER, J. D. (Eds). Animal and human relationships: the mycota. Berlin: Spring-Verlag, 1996. v. 6, p. 331-363.

LAEMMLI, U. K. Cleavage of structural protein during the assembly of the head of bacteriophage T4. Nature, Washington, v. 227, p. 680-685, 1970.

LANE, D. J. 16S/23S rDNA sequences. In: STACKEBRANDT, E.; GOODFELLOW, M. (Eds.) Nucleic acid techniques in bacterial systematics. New York: Wiley. 1991. p. 115-175.

LANE, D. J.; PACE, B.; OLSEN, G. J.; STHAL, D. A.; SOGIN, M. L.; PACE, N. R. Rapid determination of $16 \mathrm{~S}$ ribosomal RNA sequences 
for phylogenetic analysis. Proceedings of the National Academy of Sciences, Washington, v. 82, p. 6955-6959, 1985.

LATHA, J.; CHAKRABARTI, A.; MATHUR, K.; RAO, V. P.; THAKUR, R. P.; MUKHERJEE, P. K. Genetic diversity of Colletotrichum graminicola isolates from India revealed by restriction analysis of PCR-amplified intergenic spacer region of nuclear rDNA. Current Science, Bangalore, v. 84, n. 7, p. 8821-8883, 2003.

LEE, S. B.; TAYLOR, J. W. Phylogeny of five fungus-like proctoctistan Phytophthora species, inferred from the internal transcribed spacers of ribosomal DNA. Molecular Biology and Evolution, Chicago, v. 9, p. 636-653, 1992.

MEDLIN, L.; ELWOOD, H. J.; STICKEL, S. SOGIN, M. L. The characterization of enzymatically amplified eukaryotic 16S-like rRNA coding regions. Gene, Amsterdam, v. 71, p. 491-499, 1988.

MEK, A.; WARREN, H. L. Anthracnose of Sorghum. In: MILLANO, W. A. J. de, FREDERIKSEN, R. A.; BENGSTON, G. D., (Eds.). Sorghum and millet diseases: a second world review. Patancheru: ICRISAT, 1992. p. 203-208.

O'DONNELL, K. Ribosomal internal transcribed spacers are highly divergent in the phytopathogenic ascomycete Fusarium sambucium (Gibberella pulicaris). Current Genetics, New York, v. 22, p. 213-320, 1992.

PANDE, S., MUGHOGHO, L. K., BANDHYOPADHYAY, R., AND KARUNAKAR, R. I. Variation in pathogenicity and cultural characteristics of sorghum isolates of Colletotrichum graminicola in India. Plant Disease, Auburn, v. 75, n. 6, p. 124-132, 1991.
PECCHIA, S.; MERCATELLI, E.; VANNACCI, $\mathrm{G}$. Intraspecific diversity within Diaporthe helianthi: evidence from rDNA intergenic spacer (IGS) sequence analysis. Mycopathologia, The Hague, v. 157, n. 3, p. 317-326, 2004.

PECCHIA, S.; MERCATELLI, E.; VANNACCI, G. PCR amplification and characterization of the intergenic spacer region of the ribosomal DNA in Pyrenophora graminea. FEMS Microbiology Letters, Amsterdam, v. 166, n. 1, p. 21-27, 1998.

ROSEWICH, U. L.; PETTWAY, R. E.; McDONALD, B. A.; DUNCAN, R. R.; FEDERIKSON, R. A. Genetic structure and temporal dynamics of a Colletotrichum graminicola population in a sorghum disease nursery, Phytopathology, St. Paul, v. 88, n. 10, p. 10871093, 1998.

THOMPSON, J. D.; HIGGINS, D. G.; GIBSON, T. J. CLUSTAL W: Improving the sensitivity of progressive multiple sequence alignment through sequence weighting, position-specific gap penalties and weight matrix choice. Nucleic Acids Research, London, v. 22, p. 4673-4680, 1994.

VAILLANCOURT, L. J.; HANAU, R. M. Genetic and morphological comparisons of Glomerella (Colletotrichum) pathotypes from maize and from sorghum. Experimental Mycology, New York, v. 16, p. 219-229, 1992.

VALÉRIO, H. M.; RESENDE, M. A.; WEIKETOLIVEIRA, R. C.; CASELA, C. R. Virulence and molecular diversity in Colletotrichum graminicola from Brazil. Mycopathologia, The Hague, v. 159, n. 3, p. 449-459, 2005.

VILGALYS, R.; HOPPLE, J. S.; HIBBETT, D. S. Phylogenetic implications of generic concepts in fungal taxonomy: The impact of molecular 
systematic studies. Mycologia Helvetica, Bern, v. 6, p. 73-91, 1994.

WEISBURG, W. L.; BARNS, S. M.; PELLETIER, D. A.; LANE, D. J. 16S ribosomal DNA Amplification for phylogenetic study. Journal of Bacteriology, Washington, v. 173, p. 697-703, 1991.

WELSH, J.; McCLELLAND, M. Fingerprinting genomes using PCR with arbitrary primers. Nucleic Acids Research, London, v. 18, p. 72137218, 1990.

WHITE, T. J.; BRUNS, T.; LEE, S.; TAYLOR. $\mathrm{J}$. Amplification and direct sequencing of fungal ribosomal RNA genes for phylogenetics. In:
INNIS, M. A.; GELFAND, M. D.; SNINSKY, J. J.; WHITE, T. J. (Eds.). PCR Protocols, a guide to methods and applications. San Diego: Academic Press, 1990. p. 315-322.

WILLIAMS, J.; KUBELIK, A.; LIVAK, K.; RAFALSKI, A.; TINGEY, S. DNA polymorphisms amplified by arbitrary primers are useful as genetic markers. Nucleic Acids Research, London, v. 18, p. 6531-6535, 1990.

WISE, M. G.; SHIMKETS, L. J.; McARTHUR, J. V. Genetic structure of a lotic population of Burkholderia (Pseudomonas) cepacia. Applied Environmental Microbiology, Washington, v. 61, p. 1791-1798, 1995. 